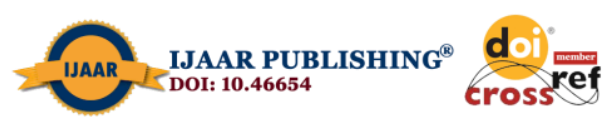

International Journal of Advanced Academic Research (Arts, Humanities and Education)| ISSN: 2488-9849

Vol. 6, Issue 4 (April, 2020) | www.ijaar.org

Journal DOI: www.doi.org/10.46654/ij.24889849

Article DOI: www.doi.org/10.46654/ij.24889849.a6425

\title{
THE STAKEHOLDERS' RESPONSIBILITIES IN MANAGING EXAMINATION MALPRACTICE IN SECONDARY SCHOOLS, IN LAGOS STATE, NIGERIA
}

\author{
ADENIRAN, FESTUS ADEWALE \\ Department of Curriculum and Instruction, \\ The College of Education, Lanlate, Oyo State, Nigeria. \\ Email: adeniranfestus@yahoo.com; Phone No: +2348029122722, +2347069253464 \\ BAKARE, KOLAWOLE MOJEED \\ Department of Curriculum and Instruction, \\ The College of Education, Lanlate, Oyo State, Nigeria. \\ Email: kolawolebakare120@gmail.com; Phone No: +2348035666424, +2348074701976
}

\author{
AKINPADE, OYEJOKE A. \\ Department of Curriculum and Instruction, \\ The College of Education, Lanlate, Oyo State, Nigeria. \\ Email: akinpadeoyejoke@gmail.com; Phone No: +2347067212225
}

\begin{abstract}
This paper examines the stakeholders' responsibilities in managing examination malpractice in secondary schools in Kosofe Local Government, Lagos State, Nigeria. It examines the forms, causes, effects, stakeholder's responsibilities, and efforts made to curb it. As a descriptive research, the study's population is 20 secondary schools in Kosofe Local Government, Lagos State, Nigeria. The methods of selecting respondents were multi-stage and stratified random sampling techniques. The instrument used to collect data was a questionnaire tagged 'Responsibilities of Stakeholders in Managing Examination Malpractice Questionnaire' (RSMEMQ), the data collected were analyzed using frequency count and simple percent. The findings revealed that one major cause of examination malpractices in the schools was indiscipline among the students which led many of them to Examination malpractice. Other important causes include the non-implementation of examination malpractice decree and inadequate supervision of students during the examination. Efforts made by the stakeholders to curb examination malpractices were discussed and conclusions were made. The paper recommends that there should be full implementation of examination malpractices decree which stipulates a jail term of twenty one (21) years for any culprit, adequate facilities should be provided, new measurement and evaluation criteria should be used, the use of mobile phone should be prohibited in examination halls, teacher, and supervisors should be persons of proven integrity and the question of double standard should not arise. It also recommends the termination of appointment of any stakeholders such as examination officials, teachers, staff assistants, and managements, who perpetrate examination malpractice and that serious punishment should be enforced to serve as a deterrent to others who may have such intension in future.
\end{abstract}

Keywords: Examination Malpractices, causes, form, effort made, stakeholders. 


\section{Introduction}

Assessment has been generally accepted as the best means of examinations. This is a formal test of ability, capability or knowledge. In fact in a school setting, examination is a means of evaluating the quality of knowledge a student has acquired within a specific period of time.

Emaikwu (2012) sees examination as part of evaluation in education which is aimed at determining a learner's/student's level of skill acquisition or intellectual competence and understanding after a given training. This evaluation usually enables the teacher to be effectively ready for further teaching as this forms a feedback. Teaching and learning become more effective when students are subjected to an examination process to determine the extent to which they have assimilated the content of the introduction given and the teacher can also assess himself from the performance of the students.

Akaranga and Ongong (2013) observe that examination is not only a process of assessing the progress of learners/students but, it also motivates and helps them to know their academic strength and weakness apart from providing teachers with opportunity to try new methods of teaching. When examination is not properly conducted, the expected feedback may not have a good result. Hence, the result of such evaluation leads to wrong decision and judgment which negatively affect the teacher, the learners and the education industry, as well as the society in general (Ojonemi, Enejor, Enejorh and Olatunmibi, 2013).

Unfortunately, this all important means of assessing students has become ineffective as all forms of malpractice have been introduced into the education system. Andesine (2000) in Omemu (2015) traces the history of examination malpractice in Nigeria in 1914, when there were leakages of the Cambridge examination. Cheating became widespread in our school environment. Hence, a special commission of inquiry headed by Alexander called Alexander commission was set up to investigate incidences of malpractice in Nigeria.

In 1977, during the West African School Certificate School Examination, there was a widespread leakage of examination questions. The government took it as a challenge to address the issues of examination malpractice in our beloved society. In 1986, a special conference was held at Ibadan in that regard. Degrees were promulgated, schools were sanctioned, results were cancelled and invigilators arrested all in a bid to curb malpractice. The irony of it all is that despite the several attempts made by stakeholders to bring an end to examination malpractice, it is still on the increase in various schools. There is a need to look into the causes, effects and current measures taken to discourage, prevent and address cheating in all categories of examination.

\section{Forms of Examination Malpractice}

Ojerinde (2004) and ANCOPSS (2006) discover forms of examination malpractices that exist or are very common at a particular time in all educational levels- primary, secondary, and tertiary. However, the examination malpractice arranged in the order in which 
they happened as presented by Ojerinde (2013) would be adopted in this paper to handle forms of examination malpractice. According to him, examination malpractice can be categorized/classified with three phases, which are as follows: i. Pre-examination, ii. During examination and iii. Post examination irregularities.

\section{i. Pre-Examination Phase:}

In secondary school the principal is an accounting officer who registers students and at times, he/she usually registers too many candidates than the available infrastructural facilities that can cope with over-registration of candidates for examination. This is one of the most common malpractices at this stage. Olowoand Ogunyemi (2014) made reference to one school in Ibadan, Oyo-state where in year 2002 a researcher was a supervisor (WAEC), the principal registered six hundred and ninety students for examination whereas the available examination hall could only accommodates four hundred candidate. The students of other classes from SS1 to 2 were forced to go on compulsory holiday as all the available classes in the school were used as examinations hall/rooms.

Over registration of candidates for school examination is closely linked with registration of non-school candidate. Also, SS2, non-school candidate and SS3 students of urban schools prefer to write their examination in remote areas where proper monitoring and adequate supervision of examination will not be ensured.

Another form of examination malpractice that occurs before the examination is the type of registration that gives room for impersonation. In this, there are two dimensions of malpractice. In the first one, a candidate registers with his/her names but submits the photograph of another person who will do examination for him/her. This was done until the time WAEC, NECO and other examination bodies decided to emboss photographs of candidates on their certificate. For the second dimension of this irregularity, the candidate fills two forms, one for himself/herself and another one for the "mercenary". On the day of examination, in the examination room, the hired candidate will write the name of his hirer, which is finally submitted. The original candidates write in the name of the mercenary and he/she may not attempt any question at all.

Likewise, appointment/selection and posting of supervisors sometimes constitute examination malpractices. Some of these private proprietors of school and college collaborate with the officials of examination bodies to post cooperating supervisors, who are usually lavishly entertained to their schools. Ojerinde (2013) explains the true story of a woman in Ikirun, Osun state; during the examination a search was conducted on her and the scanner indication showed that there were foreign metal objects in her body. All entrainment failed until a woman supervisor had to take her to a closet and undressed her only to discover that a handset was prepared just like a pad, in her private part. It was that bad, if we had not used a scanner they could not have detected it. Ojerinde (2012) observes another candidate caught 
with handset hidden in his slippers in an odd place with the intention to cheat at JAMB Examination center along with UTME official in March 2012 (Ojerinde, 2013).

\section{During Examination Phase:}

Irregularities during examinations take different forms and have acquired various names. According to Adedokun, Ogunfunniyi (2004) \& ANCOPSS (2006), malpractice at this phase includes;

$>$ Exchange of answer scripts by candidates;

$>$ collecting any form of assistance from within and outside the examination hall;

$>$ candidate using of sign language during examination;

$>$ use of GSM handset to communicate during examination;

$>$ using of public address system to dictating answers to the candidates in the examination rooms;

$>$ obstruction aimed at impeding detection of examination malpractice;

$>$ substituting answer scripts during examination

$>$ allow verbal discussion among candidates in the examination room;

$>$ taking prepared answer to the candidate in the examination room; and

$>$ Copying answers from other candidates during examination.

\section{Post Examination Phase;}

At this phase, it involves submission of a script written outside to replace another one written by the original candidate in the examination room. This post examination malpractice phase is called "slot in" or substitution. Post examination malpractice may take two different forms. The first one is a candidate may sit in the examination room fumbling with the question while a hired expert is already writing for him/her somewhere outside the examination hall. The paper written by the person called expert is finally submitted to replace the one written by the original candidate. The second way could be non-appearance, in this case, the candidate does not appear/show up at all for the examination but the examination would be taken on his/her behalf by a mercenary.

Another form of post examination malpractice phase usually involves the examination officials who work in the computer unit where they change candidate's marks in the computer database.

Review of literature on examination malpractice had revealed that some candidates try to trace their scripts to where they were being marked. Ayodele (1988) reports a case where a lady put her beautiful picture inside the scripts with a note that she would be available to any marker who was ready to cooperate with her. Some candidate enclosed money and phone number inside their scripts in order to solicit for illegal favour. 


\section{The Actors and Causes of Examination Malpractice:}

The actors of examination malpractices range from stakeholder such as officials of examination bodies, ministry of education, school administration, proprietors, teachers, nonteaching staff, students, parents, community and security agents.

The causes of examination malpractice on the whole reflect cutting-corner syndrome in Nigeria society. The meaning of cutting corner is the get rich quick syndrome.

Among other causes, the following have been identified by Oyeyinka (1998) and ANCOPSS (2006).

- Inadequate facilities in the secondary schools. Some of our secondary schools were not properly taken care of because of non-chalant attitude towards education that leads to inadequacy of necessary infrastructural facilities such as furniture, science laboratories, language laboratory and material that are necessary for impacting knowledge to the students/learners. Adeyemi (2010) says in most cases where the facilities are available, they are usually in bad condition or bad state;

- poor preparation of candidate for external examination;

- high rate/level of corruption in the society;

- poor remuneration for teachers;

- increase of private secondary schools in the late 1980s and Early 1990s whose motive is to make profit;

- poor state of nation's economy, which makes it difficult for most parents to buy necessary textbooks and other materials needed for their wards;

- desperation of parents and communities to ensure that their wards pass by all means;

- excessive registration fees charged by some principals of secondary schools;

- there is too much emphasis on certificate rather them demonstration of necessary skill;

- excessive over-reliance on certificates;

- lack of interest in hard work;

- some unscrupulous Nigerians have made it to the top without their sweat;

- over-loaded syllabus and insufficiency of essential teaching materials; and

- lack of moral instruction and good examinations ethics at all levels of schools.

\section{Effects of Examination Malpractice}

- Examination malpractice leads to irreversible loss of credibility;

- leads to dismissal, termination of appointment, loss of position which cause embarrassment and suffering to individuals, families and the nation as a whole;

- it can lead to armed banditry and sundry crimes in society;

- dissuade the learners/students from facing their studies/ from hard work; and

- low productivity and poor job performance; 


\section{Stakeholders' Responsibilities in Managing Examination Malpractice in our Education} sector

Education is a change agent that helps in inculcating right types of attitude and skills required for survival in the society. Therefore, society can only sustain tempo of development through education. This development through education has been evaluated through examination and some of the learners are looking for easy way to success through examination malpractices. This is the reason why the stakeholders have to take it as responsibility in managing examination malpractices in our educational sector. This section of the paper attempts to discuss responsibilities of education stakeholders in managing examination malpractices. The stakeholders identified in the paper are government, ministry of education, school administrators/principals, headmasters, provosts, rectors, vice chancellors, teachers, lecturers, parents, students and community at large.

According to Atanda (2014), apart from being the owner of public schools, government sets framework within which both private and public schools have to operate. The concerns of Federal Government for managing examination malpractices includes:

- Adequate funding: Planning and implementation phases in examination malpractice require money and over the years, federal government has not been able to meet the need of our examination bodies such as WAEC, NECO, NATAB, JAMB,UMTE, etc;

- regular review of existing curriculum;

- effective quality assurance mechanism;

- motivating school personnel through good welfare package; and

- provision of adequate resources, such as materials and human resources.

\section{School Administrators}

School administrators are the implementers of examination policies and guidelines. Their responsibilities in managing examination malpractice cannot be overemphasized. They act as link between ministries/government and other stakeholders in the school system i.e lecturers, teachers, non-academic staff and students. Precisely, the relevance of school administrators revolves round the following:

- Commitment of curriculum meant to guarantee free/ managing examination malpractices. This failure to demonstrate their worth during the examination as school administrators could impair school activities thereby result in examination malpractice as school failure;

- maintenance of regular and effective supervision;

- ensuring of adequate implementation of development-oriented curriculum;

- maintenance of good healthy relationship with local community; and

- ensuring good mentoring.

\section{Teacher}


Adeniran F.A, Afolabi, S.S, Akinpade, O.A \& Ogunnaiya R.T. (2011) defined teacher as someone that facilities the total development of the cognitive, affective and psychomotor domain of learners/students.

Teachers throughout the whole world are regarded as nation builders: they counsel, instruct, mould, train, discipline and encourage the learners/students in their custody. Their position cannot be eliminated in disseminating curriculum to the learners, therefore, their relevance is important in attaining good management of examination malpractice. The following are the teachers concerns if only effective education will guarantee freedom from examination malpractice.

Technologically Driven: As the whole world is a global village, there is a shift from traditional chalk and talk method of teaching to the use of technological tools like interactive board, computer, projector etc.

$>$ Thirst for knowledge and regular update of their knowledge: vast knowledge in their area of specialization will help in offering new things to the learners/students.

$>$ Transformation from teaching to facilitations: To managing the examination malpractice, the teachers have to assume a new status to be able to meet up with global challenges. They should see themselves as facilitators in global era. They only have to guide the learners/students in knowing what they need to know.

$>$ Provision of objective feedback on curriculum being implemented: Curriculum as running way, it is subject to review and will be allowed to accommodate some changes. So, teachers need to provide feedback based on their experience in the process of implementing curriculum at hand.

\section{STUDENTS}

The students are the centre of focus of teaching and learning process. Their readiness, willingness and the way they are treated matter a lot in realizing success in academics. The concerns to managing the examination malpractice include the following;

$>$ Willingness to learn

$>$ Class participation.

\section{Community at Large}

Community in the paper includes employers of labour, non-governmental organization, private sectors, and parents.

In Nigeria, parents want quick success for their wards by all means, because they have interest in good success to their children. These responsibilities include; purchase of recommended materials and provision of good nutrition. Likewise their attendance at parentsteachers Association (PTA) or parent forums meetings and open-day, helps to supervise assignment given to their children. Donations to schools in cash and kind as well as 
suggestions towards managing examination malpractice in school are among important roles expected from parents.

Private sector and employers are also stakeholders in education. They have to relate meaningfully with schools. Their information on how to manage examination malpractice so as to meet societal challenges and employment requirement are crucial. This could help in no small measure to incorporate skills that are needed to qualify for good new jobs into school curriculum (Atanda, 2014).

\section{Efforts Made to Curb Examination Malpractices}

- Ojerinde (2013) says we seek EFCC's assistance by sending circular to the Economic and Financial Crimes Commission because EFCC might not be limited to catching corrupt politicians alone but to also assist in curbing myriad of malpractices playing the conduct of public examination in Nigeria.

- Using of biometric data machines to capture candidate's information for examination in year 2012;

- Enactment of twenty one years imprisonment for examination offenders;

- Demotion or dismissal of any stakeholder engaged in examination malpractice;

- Embossment of photograph on candidate certificates with their sex and date of birth;

- Introduction of computer based test; and

- Introduction of E-testing since 2013.

\section{Statement of the Problem}

The regular occurrence of examination malpractices has been a major concern of educationists. Despite the high premium placed on examinations by the National Policy on Education (2013), it seems that examination malpractices have not been properly looked into in Nigeria. Common findings have shown that there is mass cheating in public examination in our society. Nothing concrete has been done to reduce the problem except the cancellation of results in certain subjects. The problem of the study is to find a lasting solution to the issue of examination malpractices among secondary school students in Kosofe Local Government, Lagos State, Nigeria.

\section{Purpose of the study}

The main purpose of this study is to examine the role of stakeholders in curbing examination malpractice in secondary schools in Nigeria. Specifically, the following are specific purpose:

i. Examine the meaning, forms and causes of examination malpractice;

ii. Examine the factors/devices used in accomplishing examination malpractices in secondary schools;

iii. To examine the responsibilities of stakeholders in managing/curbing the examination malpractice; 
iv. To what extent are the effects of examination malpractice on national development; and

v. Investigate the ways by which examination malpractice can be managed by the stakeholders.

\section{Significance of the Study}

This paper will be of benefit for the students, teachers, school, parents, examination bodies, Ministry of Education, educational administrators and society in general. It will improve the students' general performance at any level of education. It will let the parents realize that the way their children are performing academically and socially are as a result of whether they attend schools or otherwise. Also, educational administrators, ministry of education and society to employ trained teachers to teach students in the school, since they require better handling of desired output/objectives. Likewise the study has brought to the public awareness predicable solution to the problem of examination malpractices:

1. the study has brought to public awareness practicable solution to the problem of examination malpractices;

2. the study has also exposed the menace of examination malpractice to ensure credibility of certificate issued in Nigeria educational system.

\section{Research Questions}

The study would attempt to provide answers to the following research questions:

1. What are the perceived causes of examination malpractice in secondary school in Lagos state, Nigeria?

2. What are the identified devices used in examination malpractices in secondary schools in the state?

3. What are the responsibilities of stakeholders in community relation in managing examination malpractice in schools?

4. What are the effects of examination malpractice on the students, teachers, schools and the society in general?

5. What measures are currently taken to discourage, prevent, stop or otherwise address cheating in public examination in secondary school in Lagos state?

\section{Methodology}

The research design adopted for this study is descriptive survey. The population of the study consisted of teachers and principals in Kosofe Local Government, Lagos State public and private secondary schools. One hundred and fifty teacher $150(75 \%)$ and fifty principals representing $25 \%$ of sample take part in the study.

\section{Instrumentation}

The study made used of structured questionnaire titled: The Responsibilities of Stakeholders in Managing Examination Malpractices Questionnaire (RSMEMQ). Managing 
educated information from the respondents on how well they agree with the statement that deals with the responsibilities of the stakeholders against examination malpractice. The questionnaire was divided into two part, A and B. Part A sought information on the name of the school, its ownership (whether public or private) and its location (whether urban or rural). Part B, consist of five sections/parts; Section A: Elicited information on the perceived causes of examination malpractice in public examination in the secondary school. Section B sought information on devices usually used in examination malpractice in the secondary schools. Section $\mathrm{C}$ sought information on the responsibilities of stakeholders in managing examination malpractices in secondary schools. Section D elicited information on effects of examination malpractice on students, teachers, school and society in general while section E required information on other measure that should be taken to discourage, prevent, stop and address examination malpractices in public examination in our secondary school in Nigeria.

\section{Validation of the Instrument}

Validity of the instrument was ensured through the scrutiny of the questionnaire by experts in the field of educational management and test and measurement who matched all the items of the questionnaire with the research questions to ascertain whether or not the instrument actually measured what it was supposed to measure. Their comments served as a guide in making necessary correction on the instruments.

Reliability: The reliability of the instruments was determined using the test-retest reliability technique (Gay, 1996). In doing this, the instruments were administered to 50 respondents drawn from 10 schools outside the study area. After a period of two weeks, the instruments were re-administered to the same respondents. The data collected on the two tests were correlated by using the Pearson Product Moment Correlation Analysis. A correlation coefficient of 0.78 was obtained indicating that the instrument was reliable for the study.

\section{Administration of instrument}

The researchers personally administered the questionnaire. The researchers were however assisted by principals and teachers who teach in the sampled schools.

\section{Method of Data Analysis}

Frequency counts, simple percentages were the statistical tools employed in the study to analyze the data collected. 
Research question 1: What are the perceived causes of examination malpractice in secondary school in Lagos state Nigeria?

Table 1. Mean rates of respondents on perceived causes of Examination malpractice in secondary school in Lagos state, Nigeria.

\begin{tabular}{|l|l|l|l|l|l|l|l|l|l|}
\hline S/N & STATEMENT & SA & \% & A & \% & D & \% & SD & \% \\
\hline 1. & Fear of failure & 90 & 45 & 85 & 42.5 & 13 & 6.5 & 12 & 6 \\
\hline 2. & Craze for certificate & 180 & 90 & 20 & 10 & & & & \\
\hline 3. & $\begin{array}{l}\text { Desire of parents to have their children in } \\
\text { choice professions at university. }\end{array}$ & 76 & 38 & 104 & 52 & 12 & 6 & 8 & 4 \\
\hline 4. & $\begin{array}{l}\text { Pressure on students to pursue courses for } \\
\text { which they have no aptitude. }\end{array}$ & 104 & 52 & 76 & 38 & 8 & 4 & 12 & 6 \\
\hline 5. & $\begin{array}{l}\text { Pressure on teachers who want to gain } \\
\text { favour of the students }\end{array}$ & 30 & 15 & 50 & 25 & 70 & 35 & 50 & 25 \\
\hline 6. & Overcrowded sitting arrangement & 86 & 43 & 84 & 42 & 15 & 7.5 & 15 & 7.5 \\
\hline 7. & Poor teaching & 120 & 60 & 80 & 40 & & & & \\
\hline 8. & Ineffective preparation by students & 190 & 95 & 10 & 5 & & & & \\
\hline 9. & Ill-equipped library facilities & 90 & 45 & 100 & 50 & 10 & 5 & 00 & \\
\hline 10. & Dubious admission policy & 90 & 45 & 80 & 40 & 25 & 12.5 & 5 & 2.5 \\
\hline 11. & $\begin{array}{l}\text { General indiscipline among students in } \\
\text { the schools }\end{array}$ & 195 & 97.5 & 5 & 2.5 & & & & \\
\hline 12. & $\begin{array}{l}\text { Ineffective supervision of students in the } \\
\text { schools }\end{array}$ & 70 & 35 & 80 & 40 & 32 & 16 & 28 & 14 \\
\hline 13. & $\begin{array}{l}\text { Leakage of examination questions } \\
\text { through examination officers }\end{array}$ & 101 & 50.5 & 29 & 14.5 & 45 & 22.5 & 30 & 15 \\
\hline
\end{tabular}




\begin{tabular}{|c|l|l|l|l|l|l|l|l|l|}
\hline 14. & $\begin{array}{l}\text { Non-implementation of the examination } \\
\text { malpractices decree which provides for } \\
\text { the imprisonment of culprits }\end{array}$ & 150 & 75 & 10 & 5 & 30 & 15 & 10 & 5 \\
\hline 15. & $\begin{array}{l}\text { Leakage orchestrated by the school } \\
\text { authorities }\end{array}$ & 50 & 25 & 30 & 15 & 70 & 35 & 50 & 25 \\
\hline
\end{tabular}

Source: Field work 2019

In table 1, the opinion of the respondents varied on perceived causes of examination malpractice in secondary schools in Lagos State. One major cause of examination malpractices given by two hundred $(200 \%)$ of the respondents $(100 \%)$ was the general indiscipline among the students in the school. Another important response given by two hundred (200) of the respondents (100\%) was ineffective preparation by students, other responses include craze for certificate (200) (100\%), poor teaching, fear of failure 200 (100\%), ill-equipped library 190 (95\%), desire of parents to have their children in choice professions in university and pressure on students to pursue courses which they have no amplitude had 180 respondents which is (90\%). Overcrowded sitting arrangement, dubious admission policy had 170 (65\%) respondents agreed. Non-implementation of examination malpractice decree which provides for the imprisonment of culprits and ineffective supervision of students in the school had 160 respondents $(80 \%)$ agree. $160(80 \%)$ of respondents agree that leakages of question paper through examination officers is one of the causes of examination malpractices while leakages by the school authorities and pressure on teacher who want to gain favour of the students had 120 respondents $(60 \%)$ disagree as the causes of examination malpractices.

Research question 2: What are the identified devices used in accomplishing examination malpractice in the schools?

\begin{tabular}{|l|l|l|l|l|l|l|l|l|l|}
\hline S/N & \multicolumn{1}{|c|}{ STATEMENT } & SA & \% & A & \% & D & \% & SD & \% \\
\hline 1. & $\begin{array}{l}\text { Bringing prepared answers to } \\
\text { examination halls }\end{array}$ & 100 & 50 & 95 & 47.5 & 2 & 1 & 3 & 1.5 \\
\hline 2. & $\begin{array}{l}\text { Intimidation/assault on examination } \\
\text { officials }\end{array}$ & 80 & 40 & 40 & 20 & 54 & 27 & 26 & 13 \\
\hline 3. & $\begin{array}{l}\text { The use of coded sign language by some } \\
\text { students/giraffing }\end{array}$ & 70 & 35 & 80 & 40 & 26 & 13 & 24 & 12 \\
\hline 4. & $\begin{array}{l}\text { Hiring other people to copy answers } \\
\text { directly from textbooks during } \\
\text { examination }\end{array}$ & 101 & 50.5 & 90 & 45 & 5 & 2.5 & 4 & 2 \\
\hline 5. & $\begin{array}{l}\text { Copying other students' work during } \\
\text { examination or sending photocopies } \\
\text { during the examination to candidates }\end{array}$ & 180 & 90 & 18 & 9 & 1 & 0.5 & 1 & 0.5 \\
\hline 6. & $\begin{array}{l}\text { School authorities colluding with } \\
\text { examination officers and invigilators to } \\
\text { assist students during }\end{array}$ & 113 & 56.5 & 47 & 23.5 & 31 & 15.5 & 09 & 4.5 \\
\hline
\end{tabular}




\begin{tabular}{|l|l|l|l|l|l|l|l|l|l|}
\hline \hline & $\begin{array}{l}\text { examination/bribery, invigilators } \\
\text { conniving with students to cheat in } \\
\text { examination halls. }\end{array}$ & & & & & & & & \\
\hline 7. & $\begin{array}{l}\text { Writing the examinations in special } \\
\text { centres noted for examination } \\
\text { malpractices }\end{array}$ & 188 & 94 & 12 & 6 & & & & \\
\hline 8. & $\begin{array}{l}\text { Scientific malpractice/the use of mobile } \\
\text { phone during examination }\end{array}$ & 116 & 58 & 65 & 32.5 & 9 & 4.5 & 10 & 9.5 \\
\hline
\end{tabular}

Source: Field work 2019

Table 2 shows the divergent views of the respondents on the devices used in examination malpractice in secondary school at Kosofe Local Government, Lagos State. 200 of the respondents $(100 \%)$ claimed that writing the examination in special centers noted for examination malpractices, other devices given by the respondents include copying other students' work during examination or sending photocopies during the examination to candidates (198) (99\%). Bringing prepared answers to examination halls (195) (97.5\%), and hiring other people to copy answers directly from textbooks during examination (191) (95.5\%). For scientific malpractice/the use of mobile phone during examination (181) (91.5\%). $160(80 \%)$ claimed that school authorities colluding with examination officers and invigilators to assist students during examination/bribery, invigilators conniving with students to cheat in examination halls. The use of coded sign language by some students/giraffing claimed $150(75 \%)$ while 120 respondents (60\%) says that intimidation/assault on examination officers on average of $\frac{1557}{1800} \times 100=86.5 \%$ of respondents $(86.5 \%)$ claimed that all the devices were employed in perpetrating examination malpractices in the schools.

\section{Research Question 3}

What are the responsibilities of the stakeholder in community relation in managing examination malpractice?

\begin{tabular}{|l|l|l|l|l|l|l|l|l|l|}
\hline S/N & \multicolumn{1}{|c|}{ STATEMENT } & SA & \% & A & \% & D & \% & SD & \% \\
\hline 1. & $\begin{array}{l}\text { Effective supervision of teaching and non- } \\
\text { teaching staff minimizes the incidence of } \\
\text { examination malpractice in Secondary } \\
\text { School }\end{array}$ & 180 & 90 & 12 & 6 & 5 & 2.5 & 3 & 1.5 \\
\hline 2. & $\begin{array}{l}\text { Paying attention to the welfare and the } \\
\text { needs of school personnel these will } \\
\text { reduces the incidence of malpractice. }\end{array}$ & 72 & 36 & 102 & 51 & 18 & 9 & 8 & 4 \\
\hline 3. & $\begin{array}{l}\text { Provision of guidance and counseling } \\
\text { services to assist students in the choice of } \\
\text { career would reduce examination } \\
\text { malpractice }\end{array}$ & 89 & 44.5 & 91 & 45.5 & 3 & 1.5 & 17 & 8.5 \\
\hline 4. & Provision of security during examination & 171 & 85.5 & 12 & 6 & 10 & 5 & 7 & 3.5 \\
\hline
\end{tabular}




\begin{tabular}{|c|c|c|c|c|c|c|c|c|c|}
\hline & $\begin{array}{l}\text { by the stakeholders would prevent } \\
\text { examination malpractice }\end{array}$ & & & & & & & & \\
\hline 5. & $\begin{array}{l}\text { Stakeholders enforcement of the rules and } \\
\text { regulations guiding examination would } \\
\text { reduce the case of examination malpractice }\end{array}$ & 181 & 90.5 & 3 & 1.5 & 5 & 2.5 & 1 & 0.5 \\
\hline 6. & $\begin{array}{l}\text { Melting out of number for those who } \\
\text { engaged in examination malpractice by the } \\
\text { stakeholder would go a long way in } \\
\text { reducing it }\end{array}$ & 85 & 42.5 & 78 & 39 & 20 & 10 & 17 & 8.5 \\
\hline 7. & $\begin{array}{l}\text { When stakeholder communicate students' } \\
\text { progress in schools to parents, this would } \\
\text { prevent examination malpractice }\end{array}$ & 101 & 50.5 & 69 & 34.5 & 18 & 9 & 12 & 1 \\
\hline 8. & $\begin{array}{l}\text { Examination malpractice would be } \\
\text { reduced if stakeholders and students are } \\
\text { educated about the effects of examination } \\
\text { malpractice }\end{array}$ & 150 & 75 & 30 & 15 & 7.5 & & 5 & 2.5 \\
\hline 9. & $\begin{array}{l}\text { Organizing public enlightenment / } \\
\text { awareness for members of the community } \\
\text { by the principal about the causes and } \\
\text { consequences of examination malpractices }\end{array}$ & 110 & 55 & 85 & 42.5 & - & - & 5 & 2.5 \\
\hline 10. & $\begin{array}{l}\text { Inclusion of value, norms and custom of } \\
\text { the community cherished by students in } \\
\text { the curriculum would reduce examination } \\
\text { malpractices }\end{array}$ & 80 & 40 & 83 & 16.5 & 17 & 8.5 & 20 & 10 \\
\hline 11. & Provision of adequate learning materials & 90 & 45 & 81 & 40.5 & 7 & 3.5 & 22 & 11 \\
\hline 12. & $\begin{array}{l}\text { Regular and adequate reinforcement for } \\
\text { successful students in academic } \\
\text { performance by stakeholders }\end{array}$ & 111 & 35.5 & 69 & 23 & 12 & 6 & 08 & 04 \\
\hline 13. & $\begin{array}{l}\text { Effective implementation of the } \\
\text { continuous assessment (CA) by the } \\
\text { teachers }\end{array}$ & 107 & 53.5 & 73 & 36.5 & 11 & 5.5 & 9 & 4.5 \\
\hline 14. & $\begin{array}{l}\text { Proper planning of school curricular } \\
\text { activities }\end{array}$ & 149 & 74.5 & 27 & 13.5 & 12 & 6 & 12 & 6 \\
\hline 15. & $\begin{array}{l}\text { Establishment of examination committee } \\
\text { to look into validity and reliability of any } \\
\text { proposed examination }\end{array}$ & 138 & 69 & 45 & 22.5 & 16 & 8 & 17 & 8.5 \\
\hline 16. & $\begin{array}{l}\text { Allow the subject teachers to participate in } \\
\text { WAEC and NECO examiners coordination } \\
\text { and marking exercises }\end{array}$ & 159 & 79.5 & 16 & 8 & 10 & 5 & 15 & 7.5 \\
\hline 17. & $\begin{array}{l}\text { Encourage teacher participation in service } \\
\text { training, workshop and professional } \\
\text { organization }\end{array}$ & 82 & 41 & 88 & 44 & 11 & 5.5 & 19 & 9.5 \\
\hline
\end{tabular}




\begin{tabular}{|c|c|l|l|l|l|l|l|l|l|}
\hline 18. & Provision of right and qualified personal & 93 & 46.5 & 83 & 41.5 & 7 & 3.5 & 17 & 8.5 \\
\hline
\end{tabular}

Table 3 above shows that the relevance of the stakeholder in his community relation in managing the examination malpractice shows interesting in his community relation in managing examination malpractices on effective supervision of teaching and non-teaching staff will minimize the incidence of examination malpractices in our education sectors (192, 96\%). They agreed that if the stakeholders enforce the rules and regulations guiding examination it would reduce the case of examination malpractices and 195 (97.5\%) respondents agreed that organizing public enlightenment/awareness of examination malpractices would prevent examination malpractices. Total number of 183 (91.5\%) respondents agree that security provision during the examination by the stakeholders would prevent examination malpractices, and establishing of examination committee to look into validity and reliability of any proposed examination. On the proper planning of school curriculum and provision of right and qualified personal, 176 (88\%) respondents agree. Allow the subject teacher to participate in WAEC and NECO examiners coordination during marking exercise, 175 (88.5\%) respondent causes failure in external examination. 174 (87\%) respondents agree that stakeholders should pay attention to the welfare and the needs of school personnel, these will reduce the incidence of examination malpractice, while 171 (85.5\%) respondents agree that provision of adequate learning materials encourage teacher participation in service training, workshop and professional organization and the principal communicate students' progress in schools to stakeholders would prevent examination malpractices were the view of $170(85 \%)$ respondents. $163(81.5 \%)$ of respondents agreed that melting out the number for those who engage in examination malpractice by the stakeholder would go a long way in reducing examination malpractice and also inclusion of value, norms and custom of the community cherished by students in the curriculum would decrease examination malpractices. And that effective implementation of continuous assessment (C.A) by the teachers, regular and adequate reinforcement for successful students in academic performance by the stakeholders would reduce examination malpractices. If the stakeholders and students are well educated about the effects of examination malpractices, $180(90 \%)$ of respondents agree also on average of $\frac{3105}{3600} \times 100=86.25 \%$ of respondents claimed could be used by stakeholders managing examination malpractice in our schools/education sectors.

\section{Research Question 4}

What are the effects of examination malpractice on the students, teachers, schools and society in general?

\begin{tabular}{|l|l|c|c|c|c|c|c|c|c|}
\hline S/N & \multicolumn{1}{|c|}{ STATEMENT } & SA & \% & A & \% & D & \% & SD & $\%$ \\
\hline 1. & $\begin{array}{l}\text { Certificates issued by our examination } \\
\text { bodies have lost credibility }\end{array}$ & 82 & 41 & 78 & 39 & 18 & 9 & 22 & 11 \\
\hline 2. & Loss of credibility by examination bodies & 120 & 60 & 80 & 40 & - & & - & \\
\hline 3. & The scourge has made a mockery of our & 134 & 67 & 66 & 33 & - & & - & \\
\hline
\end{tabular}




\begin{tabular}{|l|l|l|l|l|l|l|l|l|l|}
\hline & educational system & & & & & & & \\
\hline 4. & $\begin{array}{l}\text { Rendered regular attendance in school and } \\
\text { moral teaching in schools to notes }\end{array}$ & 180 & 90 & 20 & 10 & - & & - & \\
\hline 5. & $\begin{array}{l}\text { Making nonsense of school discipline and } \\
\text { moral teaching in schools }\end{array}$ & 171 & 85.5 & 29 & 14.5 & - & & - & \\
\hline 6. & Loss of confidence on the part of students & 108 & 54 & 185 & 92.5 & 12 & 6 & 43 & 16.5 \\
\hline 7. & $\begin{array}{l}\text { Increase in the cost of conducting } \\
\text { examination }\end{array}$ & 177 & 88.5 & 23 & 11.5 & - & & - & \\
\hline 8. & $\begin{array}{l}\text { Waste of time and resources. Some of the } \\
\text { students who were "helped" usually drop } \\
\text { out of higher institutions }\end{array}$ & 86 & 43 & 114 & 57 & - & & - & \\
\hline 9. & $\begin{array}{l}\text { Discouragement of students from hard } \\
\text { work, low productivity and poor job } \\
\text { performance }\end{array}$ & 81 & 40.5 & 79 & 39.5 & 17 & 8.5 & 23 & 11.5 \\
\hline 10. & $\begin{array}{l}\text { Loss of some students into other areas of } \\
\text { misconducts such as armed robbery, } \\
\text { prostitution }\end{array}$ & 92 & 46 & 78 & 39 & 24 & 12 & 6 & 3 \\
\hline 11. & $\begin{array}{l}\text { Anyone who engages in examination } \\
\text { malpractice is building on a false } \\
\text { foundation which can lead to serious } \\
\text { professional errors }\end{array}$ & 81 & 40.5 & 104 & 52 & 09 & 4.5 & 6 & 3 \\
\hline 12. & $\begin{array}{l}\text { It's a negative orientation for future } \\
\text { leaders who may end up being fraudulent } \\
\text { offices corrupt in their various different }\end{array}$ & 183 & 91.5 & 17 & 8.5 & - & & - & \\
\hline
\end{tabular}

Source: Field work 2019

Table 4 above shows the views of respondents on the effect of examination malpractice on the students, teacher, schools and society in general in the state. $200(100 \%)$ respondents say that examination malpractices would render regular attendance in the school and moral teaching in schools useless, the examination bodies would lose credibility, increase in the cost of conducting examination, waste of time and resources, some students usually drop out of higher institution while also serve as a negative orientation for future leaders who may end up being fraudulent and corrupt in their various different offices. On the effect of examination malpractices, however, $185(92.5 \%)$ respondents agree that anyone who engages in examination malpractice is building on a false foundation which can lead to serious professional errors. Total number of $170(85 \%)$ agree that examination malpractices as scourge has made a mockery of our educational system and at the same time the respondents say that some students were lost into other areas of misconducts such as armed robbery, prostitution. Likewise, $160(80 \%)$ respondents agree that examination malpractice discourages students from hard work, low productivity and poor job performance. Also, 160 $(80 \%)$ respondents agree that certificates issued by our examination bodies have lost 
credibility while $140(72.5 \%)$ respondents agree that examination malpractices would make the students to lose self-confidence on their own parts an average of $\frac{2190}{2400} \times 100=91.25 \%$ of respondents observed that examination malpractice produces candidates with low morals and academic values and their product always end up with unfulfilled dreams in them.

\section{Research Question 5}

What measures are currently taken to discourage, prevent or otherwise address cheating in public examinations in secondary schools in the state?

\begin{tabular}{|c|c|c|c|c|c|c|c|c|c|}
\hline $\mathbf{S} / \mathbf{N}$ & STATEMENT & SA & $\%$ & $\mathbf{A}$ & $\%$ & D & $\%$ & SD & $\%$ \\
\hline 1. & $\begin{array}{l}\text { Emphasis on proficiency in skills rather } \\
\text { than certificates }\end{array}$ & 82 & 41 & 78 & 39 & 22 & 11 & 20 & 10 \\
\hline 2. & $\begin{array}{l}\text { Twenty-one years imprisonment for } \\
\text { examination offenders }\end{array}$ & 92 & 46 & 88 & 44 & 8 & 4 & 12 & 6 \\
\hline 3. & $\begin{array}{l}\text { Demotion and dismissal of any } \\
\text { stakeholder who engage in examination } \\
\text { malpractices }\end{array}$ & 123 & 61.5 & 77 & 38.5 & - & & - & \\
\hline 4. & $\begin{array}{l}\text { Sensitization of the public on the evil } \\
\text { effects of examination malpractices }\end{array}$ & 111 & 55.5 & 89 & 44.5 & - & & - & \\
\hline 5. & $\begin{array}{l}\text { Embossment of photograph, date of birth } \\
\text { and sex of candidates certificates }\end{array}$ & 164 & 32 & 36 & 18 & - & & - & \\
\hline 6. & $\begin{array}{l}\text { Various seminars, workshop to be } \\
\text { organized for candidates and school } \\
\text { authority and officers involved in } \\
\text { examination malpractices }\end{array}$ & 124 & 62 & 36 & 18 & 24 & 12 & 16 & 8 \\
\hline 7. & $\begin{array}{l}\text { Cancellation of entire or part of the result } \\
\text { of candidate caught in the act, eg. in } 1993 \\
\text { SSCE; } 39,162 \text { candidates result was } \\
\text { cancelled }\end{array}$ & 121 & 60.5 & 79 & 39.5 & - & - & - & \\
\hline 8. & $\begin{array}{l}\text { Launch serious campaign against } \\
\text { examination malpractices }\end{array}$ & 191 & 95.5 & 09 & 4.5 & - & - & - & \\
\hline 9. & Mounting of anti-malpractice bill board & 178 & 89 & 22 & 11 & - & - & - & \\
\hline 10. & $\begin{array}{l}\text { Using of security bag for collection of } \\
\text { examinational materials }\end{array}$ & 184 & 92 & 16 & 8 & - & - & - & \\
\hline 11. & $\begin{array}{l}\text { Using electronic devices to check students } \\
\text { pockets before entering the examination } \\
\text { hall }\end{array}$ & 190 & 95 & 10 & 5 & - & - & - & \\
\hline 12. & $\begin{array}{l}\text { The terminations of appointment of } \\
\text { stakeholders which aid examination } \\
\text { malpractices in the school }\end{array}$ & 191 & 95.5 & 08 & 04 & 1 & 0.5 & - & \\
\hline
\end{tabular}

Source: Field work 2019 
Table 5 shows the views of the respondents on the current measures taken by the stakeholders to discourage examination malpractices in our education sector. 200 of the respondents $(100 \%)$ claimed that all the ten items under this statement questionnaire were good current measures taken by the stakeholders to discourage examination malpractices.

Answering this question, data on the measures currently taken to prevent cheating among students of any public examination in the state were collected from the responses to the question. The data collected were analyzed using percentages. Table 5 shows the findings.

In this table, the respondents' views varied on the measures given by the respondents that could discourage or prevent cheating in examinations in the state were collected and were analyzed in the questionnaire. The data collected were analyzed by using percentages. The findings are presented in table 5 .

Table 5 shows measures given by the respondents that could discourage or prevent cheating in examination in education sectors in the state. Among the current measures, embossment of photograph, date of birth and sex on the candidate certificates, emphasis on proficiency in skills rather than certificates, twenty one years imprisonment for examinations and dismissal of any stakeholder who engages in examination malpractice using of seventy bag for collecting of examination materials mounting of only malpractice, bill board, launch serious campaign against examination malpractices, sensitization of the public on the evil effect of examination malpractice, various seminars, workshop to be organized for candidates and school authority and officers involved in examination malpractices, cancellation of entire or part of result of such candidates caught in the acts and ban schools that is involved and use of electronic biometric data devices to check students pockets before entering the examination halls. All the items were 200 (100\%) respondents each. On the average $\frac{2200}{2200} \times 100=100 \%$ respondents claimed that the measures currently suggested in table 5 should be put into consideration in order to discourage, prevent or otherwise address cheating in examination in the schools.

\section{DISCUSSION}

The foregoing shows the analysis of data collected for this study. As indicated in the findings, one important cause of examination malpractice in schools in the state is the general indiscipline among the students in the schools, craziness for certificate, desire of parents to have their children in choice professions in universities, poor teaching, ineffective preparation by students, fear of examination and non-implementation of the examination malpractice laws by government, which shows that there had been no penalty imposed on offenders in the past and the non-implementation of the examination malpractice act, many students continued to get involved in examination malpractice. It implied that since there is no punishment given to offenders to serve as a deterrent to others, examination malpractice among students in schools/educational sectors remained unmanageable. This finding is in consonance with the submission of Muazu (2011) who observes that non-implementation or enforcement of the decree has been the major obstacle to the usefulness of these measures in 
managing examination malpractice in education sector/schools in the state. Termination, suspension, demotion or outright dismissal of stakeholders like teachers, principal, ministry, or representative of examination bodies who engage in examination misconduct are ways perceived by the respondents as being effective.

Table 2 claimed that all devices were employed in perpetrating examination malpractice in the school, $86.5 \%$ of respondents agreed with the findings made in other studies (Oyekan, 1999; Ogunwuyi, 2005; Onyibe, Uma and Ibina, 2015).

On the relevance of the stakeholders in community relation in managing examination malpractice (Table 3), the study revealed that $86.25 \%$ of respondents revealed that stakeholders should be involved in the provision of guidance and counseling services to assist students in choice of career would reduce examination malpractice, security provision during examination, the rules and regulations guiding examination would reduce the case of examination malpractices, effective supervision of teaching and non-teaching staff minimizes the incidence of examination malpractice in secondary schools and proper attention should be paid to the welfare and the needs of schools personnel. These will reduce the incidence.

This finding agreed with the findings made in previous studies by Anzene (2014) and Oko and Adie (2016). The finding suggests that stakeholders should stop paying leap service to examination malpractice. Religious and community leaders should intervene by discussing with parents who insist on their children getting the best result without genuine efforts for it.

From table 4, the effects of examination malpractices on the students, teachers, schools, stakeholders and society in general, $91.25 \%$ of respondents observed that examination malpractice produces candidates with low morals and academic values and their product always end up with unfulfilled dreams in their career. They will also build on a false foundation which can lead to serious professional errors that can lead to collapse of national development.

The potentials of this nation will be difficult to realize socially, economically, and technologically until individuals, government and other stakeholders in education sector collaborate to eradicate examination malpractice.

However, on the current measures taken by the stakeholders to discourage or prevent cheating in examination in the state, $100 \%$ respondents claimed that the following measures should be taken to discourage, prevent or otherwise address cheating in school examination: punishment for examination offenders, suspension, demotion, termination of appointment or outright dismissal of principals, teachers or any stakeholder who engage in examination misconduct, and public enlightenment to curb examination misconduct. Muazu (2001) suggests that much emphasis should be placed on demonstration of skills rather than possession of certificates, embossment of candidates' photographs and date of birth on candidates' certificates, various seminars, workshop have been organized for stakeholders and officers involved in examination malpractices, using of security examination materials 
and cancellation of entire or part of result of candidates caught in the acts and ban any school involved for subsequent years. Introduction of Biometric Data capturing machines to verify authenticity of candidates with the use of the machines, candidates to sit for examination, likewise the use of continuous assessment technique; Akanni and Odofin (2015) defined continuous assessment (CA) as a continuous updating of teachers judgment about the learner's performance in relation to specific criteria which will give room for anytime a cumulative judgment to be made about his/her performance. Also, proper funding of education sector, employment of qualified teachers at all levels of education and adequately equipped school libraries and laboratories with quality books. Appropriate remuneration should be given to teachers and examination officers.

\section{Conclusion}

Since examination malpractice sows seeds of fraud and criminal values in our society, this vice cannot allow us to realize our future greatness because it renders our certificates useless and debases the foundation for assessing our skills and capacity.

Consequently, the findings of this study conclude that indiscipline among the students is a critical variable in students' involvement in examination malpractices in schools. This was evident in the findings which singled out indiscipline as a root cause of examination malpractice among students of secondary schools in the state. Examination malpractice not only promotes breakdown of moral and ethical standards in our society but it also prevents achievement of meaningful and sustainable development, for example in our aspiration to become one of the twenty economies in the world by the year 2020 .

Likewise, these findings have also led the researchers to conclude that examination malpractice will provide candidates with low moral and academic value and their product always end up with unfulfilled dreams in their career and building on a false foundation which can lead to serious professional errors. The findings have moreover led the researchers to conclude that effective supervision of student during examination is lacking in many secondary schools while the current measures taken to discourage, prevent or otherwise address examination malpractices among the students are insufficient as additional measures need to be taken. The government, parents, churches, mosque etc. may need to play complementary roles. The gospel of examination malpractices should be well preached more to the society at large.

\section{Recommendations}

Based on the research findings, the following recommendations are suggested for effective management of examination malpractice. It was recommended that there should be full implementation of the examination malpractice decree which provides for imprisonment of culprits for 21 years in Jail. Hence, the arrest and prosecution of students caught in examination malpractice should always be done to serve as a lesson to others and the need to intensify continuous assessment and aptitude test at various stages of our education system: 
Ban of selling of handout particularly in tertiary institutions to minimize incessant causes of examination malpractices as many students had been apprehended with handout in examination halls.

$>$ Examination bodies, government and stakeholders, must confront this challenge by reducing or eliminating the administrative, institutional, attitudinal and logistic problems encouraging examination malpractices.

$>$ Adequate facilities such as lecture halls, classrooms and laboratories to make the academic environment conducive not only for teaching and learning but also to ensure effective check and control of candidates during examination.

$>$ There should be major and comprehensive overhaul of the educational system in the country since education is the best legacy; that no individual or country in this contemporary world would develop with a flawed education system.

> New measurement and evaluation criteria that will reduce the burden on examination should be used as yardstick for academic progress, ability and ranking.

$>$ The cases of examination malpractices must be reduced if students must be blamed for poor preparation for examination and there must be the use of electronic devices to check students' pockets before entering the examination halls.

$>$ The ban on the use of mobile cell phones, BB and IPAD in examination, introduction of CBT Test, teachers and supervisors should be person of proven integrity and the question of double standard should not arise.

$>$ Stakeholders should stop paying leap services to examination malpractices. Religious leaders (Christian, Islam and traditionalists) and community leaders should be used to intervene on parents who insist on their children getting the best result without genuine efforts for it.

$>$ The rigidity and timing of examination should be reviewed in such a way that when students complain genuinely that he cannot write an examination another time should be organized for him, It may be in form of summer examination; this will eradicate the fear/phobia of failure which may lead to impersonation and other form of malpractices.

$>$ The gospel of examination malpractice should be preached more to the teachers than even the students in any public or private schools.

$>$ Also, students should stop looking unto teachers or their schools for assistance if such help does not exist, malpractices will be minimized.

$>$ Finally, restoring of that section of decree 20 of 1984 which stipulates that twenty-one years imprisonment should be given without any option of fine into the 1999 constitution (as amended) will be a right step in the right direction in winning this examination malpractice war. 


\section{References}

Act 33 of the (1999). Constitution of Federal Republic of Nigria as Amended.

Adedokun, I. A. (2003).Measurement and evaluation in the classrooms, Onipanu, the stronghold Education publishers. Pp. 157-172.

Adeniran, F. A., Afolabi, S. S., Akinpade, O. A. \&Ogunaiya, R. T.(2011). A Handbook on Introdution to Techear Education in Nigeria,Oyo; Adeniran Printing Press.

Adesina, S.(2002). 'Changing phenomenon in Nigerian educational system'. In Ajayi, K \&Ajayi, T. (Eds) New perspective in Nigeria education,Ibadan: Vantage publishers, Pp $2-16$.

Adeyemi, T. O (2010).Examination malpractice among the secondary school students in Ondo state Nigeria.Perceived causes and possible solution journal of Education Administration and policy studies, Vol.2 (3) AP, 48-55.

Akanni, O. O. \&Odofin B. (2015).Reducing exam malpractice in Nigeria school through effective continuous assessment (C.A) techniques as an alternative to one-shot examination in Osun state, Nigeria Africa journal of educational research.2(1):91101.

Akeranga, S. I. \&Ongong J. J. (2013). The phenomenon of examination malpractice.An example of Nairobi and Keenyalta Universal journal of Education and Practice ,4(18), 87-90

ANCOPSS Oyo State(2006). Examination Malpratices, causes, effects and recipe. The School Adminstrator 8(1), 42-52

Anzene, S. J. (2014). Trend in examination malpractice in Nigeria Educational System and its effects on the social economic and political development of Nigeria. Asian Journal of Humanity and Social Sciences (AJHSS), Vol. 2 (3):1-8.

Atanda , A. I. (2014). Quality Education for Sustainable Development: A task for every stakeholder: Educational Management in Africa. In Emunemu, B. O. \&Akinwumi , F. S. (Eds) Educational Management in Africa. Ibadan. Giraffe books 336-344.

Ayodele, S.O (1988). Problem of a Language for Educating Nigeria Learners faulty lecture series No 4, university of Ibadan.

Emaikiru, S. O. (2012). Assessing the impact of examination malpractices on the measure of ability in Nigeria. International journal of social sciences of educational, 2(4):748757. 
Jimoh, B. O. (2009). Examination Malpractice in Secondary Schools in Nigeria: What sustains it? European Journal of Educational Studies, 1 (3) pp 101-108.

Muazu, B. (2011). Examination malpractice and the quality of education in Nigeria.TheKumbolso Teacher Educator.2 (2).

Ogunfunminiyi, A. T. (2004). The impacts Academic malpractices on the development of the society.Nigeria journal of Educational productivity and contemporary issues,2(2) pp 33-33

Ogunwuyi, J. A. (2005). Strategies for coping with Indiscipline in Secondary Schools.Paper presented at the all Nigeria conference of principals of secondary schools (ANCCOPSS) at the Mandatory Continuing Professional. Training Workshop held at Osogbo, Osun state, Nigeria from March15-16, Pp 2-12.

Ojerinde Dibu (2004). Examination Malpractice in our Educational System, The NECO Experience. A Faculty of Education Lecture Series delivered at the ObafemiAwolowo University, Ile-Ife on 23rd February 2004.

Ojerinde Duju (2013). Annual newsletter for candidate of Unified Tertiary Marfiation Examination; Abuja.Bates.Cossel.

Ojonemi, P. S., Enejor W., Enejorh, N, \&Olatunmibi, O. (2013).Examiation malpractices challenges to Human Resource Development in Nigeria. Internation journal of capacity Building in Education and Management. 2(1):91-101.

Oko, S. U. and Adie, R. I. (2016). Examination malpractice: causes, effects, possible ways of curbing the menance. A study of Cross River, University of Technology.International Journal of Managerial Studies and Research (IJMSR), Vol 4 issue 1 January, 2016, pp 59-65.

Olowo, A.O. \& Ogunyemi A. O. (2014). Curbing Examination Malpractices in secondary schools.Roadmaps to educational reformation in Nigeria. In Omolayo, E.L, Opoola,B.T, Olowo G.M, Taiwo, O.A Animasahun, A G, \&Akinsowon F.I (Eds) Educational Transformation in Nigeria. A multidisciplinary approach, Lagos, FC publishing ventures Pp 292-305.

Omemu, F. (2015). Causes of Examination malpractice in Nigeria schools British journal of Education, Vol 3 No 7 Pg 31-41 July 2015.

Onyibe, C. O. Uma, U. U. and Ibina, E. (2015). Examination malpractice in Nigeria: causes, and effects an Nation Development. Journal of Education and practice 0016, (26) pp 12-18. 
Oyekan, S. O. (1999). 'Views on Examination Malpractices and Secret cult in Nigeria universities' Paper presented at the conference on cultism in Nigeria Universities hold at the Ondo State university, Ado-Ekiti from 30 -31, August; 4-9.

Oyeyinka, A. F. (1998). Teacher factors as a variable to examination malpractice. Unpublished paper presented at National Conference on Examination Malpractice. 